\title{
5. Beyond Chineseness: De-Nationalising and De-Sinicising Modern Chinese Literature
}

Irmy Schweiger

Chinese Language and Cultures, Stockholm University

\section{Introduction}

To what extent does Chinese American Ha Jin's work, written in English, with Chinese culture and politics as imaginary backdrop, qualify as Chinese literature? How about Chinese-born writer Gao Xingjian, French citizen and Nobel laureate writing in French? Are the writings of American Nobel prize laureate (I938) Pearl S. Buck, who spent most of her life in China and wrote exclusively about China, considered Chinese literature? Is Tibetan writer A-lai, who publishes fiction about Tibet in Chinese, writing Chinese literature? Is Husluma Vava, Taiwanese writer, writing in Chinese about Bunun culture, producing Chinese literature? And what of literature written in Chinese from Hong Kong, Taiwan, Malaysia and Singapore? There is no doubt: Writers of transnational and multicultural backgrounds are challenging conceptual frameworks of Chinese literature based on antagonistic binaries such as tradition and modernity, China and the west, national and local, Han Chinese and ethnic minority self, dialects and the standard language. However, the expanding corpus of literature produced by Chinese communities worldwide has only recently attracted scholarly attention to revisit histories of literary production and to challenge the concept of modern Chinese literature

How to cite this book chapter:

Schweiger, Irmy. "Beyond Chineseness: De-Nationalising and De-Sinicising Modern Chinese Literature". In World Literatures: Exploring the Cosmopolitan-Vernacular Exchange, edited by Stefan Helgesson, Annika Mörte Alling, Yvonne Lindqvist, and Helena Wulff, 42-58. Stockholm: Stockholm University Press, 2018. DOI: https://doi.org/Io.16993/bat.e. License: CC-BY. 
that is based on the notion of a monolithic Chineseness referring to mainland China exclusively.

The following chapter outlines the conceptual framework of modern Chinese literature as a highly ambivalent nationalistic and coercive vernacularisation project at the beginning of twentiethcentury China. It claims that the emergence of modern Chinese literature mainly was due to an efficient politico-cultural institutionalisation that was reinforced by canonisation, language policy and sinocentric identity discourses, framed by Marxist and teleological historiography. In recent years, however, the monolingual and sinocentric mantra has been challenged by a growing corpus produced by writers with transnational and multicultural backgrounds from Chinese communities worldwide, prompting postcolonial counterhegemonic and analytical tools to de-nationalise and de-sinicise modern Chinese literature.

\section{Modern Chinese Literature Between a Rock and a Hard Place}

The predicament of modern China has affected the narrative of modern Chinese literature and culture ever since Chinese writers and intellectuals at the turn of the nineteenth century joined forces in a patriotic tour de force to "save China" and to "build a wealthy

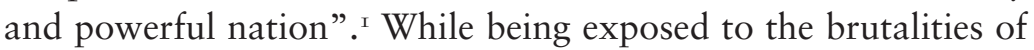
western and Japanese hegemonic imperialism on the one hand and internal social disintegration and the final collapse of the dynastical empire on the other, advocates of the New Cultural Movement sought refuge in a bold mixture of an iconoclastic anti-traditionalist worldview ("cannibalism" becoming the icon for Chinese traditional culture) and a romantic notion of western enlightenment and the modern nation-state (famously replacing " $\mathrm{Mr}$ Confucius" with "Mr Science" and "Mr Democracy"). ${ }^{2}$ It might

I On the interrelation of modernity and nationalism especially during the May Fourth period, see Zhao Suisheng, A Nation-State by Construction: Dynamics of Modern Chinese Nationalism (Stanford, CA: Stanford University Press, 2004).

2 Cf. Lena Rydholm's chapter in this volume. 
count as one of the ironies of transnational history that in late nineteenth-century China, western modernity became the object of desire when it was actually on the verge of collapsing; disillusionment and transcendental homelessness had already become the prevailing western zeitgeist and modernism an instrument of criticism instead one of affirmation.

In the China-related context, "modernisation" became equated with "westernisation" and the May Fourth period bred this primal cause that structured the cultural double bind, which would underlie any discourse on modern Chinese identity and literature through to the I980s. The schizophrenic split can thus be traced back to different though overlapping forms of the event of modernity: a coercive one, forcing modernity on the colonial subject (through the opium war); and an aspirational one, thrilled by things modern and driven by a fascination for a unified nationstate (the New Culture Movement). ${ }^{3}$

Apart from external colonisation by imperialist powers, internal colonisation by authoritarian power has simultaneously been adding to the complex situatedness of literature and culture. The established presupposition of the mutual constitution of literature and nation is notably relevant in the case of China, yet has a decidedly political notion. ${ }^{4}$ Drawing excessively on parallels of Mao Zedong's infamous "Talks at the Yan'an" in I 942,5 current

3 These paradoxical historical experiences would later not only fertilise the principal nationalistic narrative of the "century of humiliation" but also fuel "patriotic nationalism" and political campaigns fighting westernisation like the "Anti-spiritual Pollution Campaign" (I984) or "Against Bourgeois Liberalisation Campaign" (I987). Alison Adcock Kaufman, "The 'Century of Humiliation', Then and Now: Chinese Perceptions of the International Order", Pacific Focus 25, no. I (2010): I-33 and William A. Callahan, "National Insecurities: Humiliation, Salvation, and Chinese Nationalism”, Alternatives 29 (2004): I99-2I 8.

${ }^{4}$ For a closer explication, see the chapter by Lena Rydholm in this volume.

5 Mao Zedong毛澤東, “Zai Yan'an wenyi zuotanhui shang de jianghua” [Talks at the Yan'an Forum on Literature and Art: 在延安文㙯座談會上 的講話], Fenghuang wang, I4 May 2009, http://book.ifeng.com/special/ hongsejingdian/list/200905/05I4_6459_II58238.shtml.See also Mao Zedong's 'Talks at the Yan'an Conference on Literature and Art': A Translation of the I943 Text with Commentary, ed. and trans. Bonnie S. 
president $\mathrm{Xi}$ Jinping reminded artists and writers as late as in October 20I4 in his "Talks" to create works with "vivid national characteristics", and promote "socialist core values" to encourage Chinese people's "sense of national pride and honour". ${ }^{6}$ Since the Party never left much room for interpretation of the political role and social task of art and literature, the history of modern Chinese literature has consequently been read as an intersection of politics and literature moving forward in time, framed by Marxist and nation-obsessed teleological historiography.

\section{Constituting the Chinese Modern: Enlightenment \& National Salvation Narratives}

Consequently, Chinese literary history is based on two plotlines: First, as a story of modernity, making the advent of western imperialism, the subsequent May Fourth Movement (I9I9) in its pursuit of modernity and its invention of "China as a nation", the cradle of modern Chinese literature; ${ }^{7}$ second, as a sequence of "realist comments" mirroring and negotiating political and social struggles of revolutionary China, since "realism came to carry the profoundest burden of hope for cultural transformation". ${ }^{8}$ In order to unfold its educative and incisive power of enlightenment, needed for the building of new China, new literature had to be penned in the standard written vernacular language (baihua 白話) that was to replace the "dead" and static classical language (wenyan 文言). More than half a century later massive globalisation,

McDougall, Michigan Papers in Chinese Studies 39 (Ann Arbor: Center for Chinese Studies, The University of Michigan, I980).

${ }^{6} \mathrm{Xi}$ Jinping 習近平, “Zai wenyi gongzuo zuotanhui shang de jianghua” [Talks at the forum on literature and artwork 在文藝工作座談會上 的講話], Xinhua Net, I4 October 20I5, http://news.xinhuanet.com/ politics/2OI 5-IO/I4/c_I I I 6825558 .htm.

7 For a sharp summary of critical re-examinations of the discourse of Chinese modernity, see Charles A. Laughlin, "Introduction”, in Contested Modernities in Chinese Literature, ed. C. Laughlin (New York, NY: Palgrave Macmillan, 2005), I-I 5.

${ }^{8}$ Marston Anderson, The Limits of Realism: Chinese Fiction in the Revolutionary Period (Berkeley: University of California Press, I990), 3. 
commodification and de-politicisation ran rampant, post-revolutionary China then coined the slogans to "march forward" (wang qian zou 往前走) and “take to the global stage" (zou xiang shijie 走向世界). In post-Tiananmen China (I990s), literature was turned into a cultural marker of Chinese postmodernism, mainly on the basis of the constant flow of imported western theories developing a “cultural fever" (wenhua re 文化熱). 9 These master narratives have shaped literary production and scholarship for decades and have been reinforced by orientalist complicity of the academic and general reading public: the conceptualisation of "belated Chinese modernity" conveniently allowed both, perpetuating supremacy of modern western culture and backwardness of traditional Chinese culture. ${ }^{\text {IO }}$ Furthermore, it created a defining space for a malleable binary perception of modern Chinese literature as cultural hybrid: originating as a "response to the West", while at the same time making use of indigenous traditional Chinese resources.

This constellation recalls Græcist Gregory Jusdanis' critique of modernisation theories as eurocentric and chronocentric projections. Belated modernisation, he argues, manifests itself in a sort of internalised structural deficiency, as local realities are necessarily incongruent with the assumedly western originals. In order to catch up, "delayed modernization necessitates centralised planning, since it entails the anxious attempt to acquire the characteristics of a model". ${ }^{\text {II }}$ A decidedly programmatic approach to de-centralise the west by "provincialising Europe" is advocated by historian Dipesh Chakrabarty, whose approach has had a strong impact on sinological discourses. Advocating articulations

9 Zhang Xudong, Chinese Modernism in the Era of Reforms: Cultural Fever, Avant-Garde Fiction, and the New Chinese Cinema (Durham and London: Duke University Press, I997) and Wang Ning, "The Mapping of Chinese Postmodernity", in "Postmodernism in China", special issue, boundary 2 24, no. 3 (Autumn I997): I9-40.

10 It was only in the I980s, when Edward Said's Orientalism (I978) started to be discussed in the field of China Studies that "Chinese modernity" was de- and re-constructed.

${ }^{11}$ Gregory Jusdanis, Belated Modernity and Aesthetic Culture: Inventing National Literature (Minneapolis: University of Minnesota Press, I99I), xiv. 
of non-unitary experiences of political modernity, he inspired China scholars and postcolonial intellectuals. Wang Xiaoming, for example, argues for heterogeneity of the Chinese modern on the basis of a bidirectional globalisation process, passing off from outside and from inside, from the global appropriated by the local and vice versa. ${ }^{\mathrm{I2}}$ Nevertheless, during the long twentieth century, the Chinese politico-cultural elite made sure to unify experiences of modernity, to homogenise the Chinese modern and to escape the "waiting room of history" by establishing a nationalistic and sino-centric political self as the agent of local history and as a global player.

\section{Institutionalising a Modern Mode of Cultural Production: Language Policy}

Understandably, a foundational myth conveniently leaves aside everything and everyone that complicates matters. One of the New Culture Movement's main pillars is the replacement of the classical language by the vernacular, thereby creating a new language allowing for a new literature. Language policy, for that matter, was an efficient means to institutionalise the modern in cultural production. The reportedly notorious quest for a modern Chinese script at the beginning of twentieth century was, however, neither a simple national decision nor a pure mainland phenomenon. Chinese communities in Taiwan, Hong Kong, Malaysia, Singapore or Indonesia, due to these countries' colonial histories and prevailing sense of belonging to their ancestral home, were at least sensitive to the May Fourth movement's call for a new culture. ${ }^{\mathrm{I} 3}$ Political activists' breathless search for a "national

ז2 Wang Xiaoming, "The Trajectory of the 'Third World' in Early Modern Chinese Thought", Inter-Asia Cultural Studies I7 (2016): 84-90. Critics of eurocentrism argue that classical western social theory did not intend to establish modernity as a universal category but saw it as a condition characterising western societies.

I3 David Kenley, New Culture in a New World: The May Fourth Movement and the Chinese Diaspora in Singapore, I9I9-I932 (New York: Routledge Press, 2003). 
language", taking to the "vernacular" as standard-bearer for a modern literature that was to strengthen and to create an image of the nation, was however much less successful among Chinese communities outside the mainland. Regional idiolects or "topolects" like Hakka, Fukienese or Teochew stubbornly persisted and remain up to this day a marker of ethnic, linguistic and cultural distinction. ${ }^{\mathrm{I}}$

More importantly: the process of vernacularisation, "a rather militant and monolingual idea implemented and institutionalised by the May Fourth vernacular movement" was setting a dramatic end to an earlier diglossic linguistic landscape (populated with classical written Chinese and colloquial spoken dialects). ${ }^{\text {I5 }}$ In I9I2, after continuous script reforms during late Qing (I644-I9I I) and after negotiating between different regional dialects, the Ministry of Education of the newly established Republic of China decided in favour of Mandarin (guanhua 官話), an informal lingua franca that had long since been used for imperial administrative purposes, to be the new "vernacular" or "national language". ${ }^{16}$

The historical setting of this intricate transformation process was thus far from being monolingual or mono-cultural. On the contrary, leading late Qing and early Republican reformers had spend their formative years in study-abroad programs, mostly in Japan, Germany, France, Britain and America, which not only broadened their world view but also bred a peculiar nationalism. While this intellectual elite, driven by both megalomania and despair, aspired to build a strong and superior China by learning from foreign modern nations, they at the same time experienced displacement, linguistic estrangement and racist humiliation

${ }^{14}$ On the question of topolects, see Victor H. Mair, "What is a Chinese 'Dialect/ topolect'? Reflections on Some Key Sino-English Linguistic Terms", Sino-Platonic Papers, 29 (September I99I): I-52.

${ }^{15}$ Gang Zhou, Placing the Modern Chinese Vernacular in Transnational Literature (New York: Palgrave Macmillan, 20II), 7. This is, to my knowledge, the most recent discussion of the vernacularisation process in China in a critical world literature perspective.

${ }^{16}$ For details, see Robert Ramsey, The Language of China (Princeton: Princeton University Press, I987). 
exactly in the environment that inspired awe and admiration. ${ }^{17}$ Even worse, not much later they became alienated in their own country too, when their work would disqualify as "dressed in European cloth and the academism of Oxford, Cambridge and Columbia [...] an exotic banquet made for the Europeanised gentry in order to give them some exciting varieties". ${ }^{18}$ The typical May Fourth writer was not simply "a hand writing the mouth" 19 or a collector of "small talk" from the street corners and alleyways,${ }^{20}$ he actually was on a "mission impossible". ${ }^{21}$

In the decades to come Chinese language policies put a lot of effort into making the vernacular, Mandarin or putonghua (普通 話 common language) the lingua franca in Mainland China and beyond, legitimising Chinese Communist Party's national aspirations and executing its soft power not least by way of the worldwide establishment of Confucian Institutes to "spread Chinese language and culture". ${ }^{22}$

${ }_{17}$ The writings of the decadent writer Yu Dafu (I 896-I945), who spent nine years in Japan, are often read as locus classicus of a national inferiority complex, as his bold descriptions of the impotent sexual landscape of the Chinese male is read as encoding national weakness. See Yu Dafu, Chenlun (Sinking沈淪), I92 I. http://millionbook.net/mj/y/yudafu/ ydfz/oo2.htm.

I8 See Gang Zhou, Placing the Modern Chinese Vernacular, 43, quoting Qu Qiubai (I899-I935), one of the most eminent literary figures and political activist who spent many years in Russia. Apart from Chinese, Qu spoke French, Russian and English.

I9 This is a literal translation of the often-quoted catch phrase "Wo shou xie wo kou [我手寫我口]” of the late Qing scholar Huang Zunxian (I 848I905), which was often used to illustrate that the vernacular was nothing more than the spoken language written.

20 “Xiaoshuo [小說]”, a term explicated in the History of the Han Dynasty which is credited to historian Ban Gu (32-92 AD), has become the term for fiction as a vernacular genre, which, if taken literally, means small talk.

${ }^{21}$ For a critical reading of the role of May Fourth vernacular see Shumei Shih, The Lure of the Modern: Writing Modernism in Semicolonial China, I9I7-I937 (Berkeley: University of California Press, 200I), 7I.

${ }^{22}$ For a recent article on the issue see Rachelle Peterson, "American Universities Are Welcoming China's Trojan Horse”, Foreign Policy, 9 May 20I7, or the publications by the National Association of Scholars (NAS), https://www.nas.org/projects/confucius_institutes/the_report. 


\section{Canonisation of Modern Literature}

Nationalism and sinocentrism were not only reflected in language policies but were just as well exhibited by the literary canon which by and large was set by a chauvinist communist ideological apparatus and found its first revisions only in the I970s. ${ }^{23}$ Those revisions meant a cautious extension of the canon by integrating "marginal" women writers together with "neglected" literary schools and individual literary figures. The national project of "rewriting literary history" (chongxie wenxue $s h i$ 重寫文學史) in the late I980s was, however, more radical in questioning the "West-response" presupposition by pioneering explorations of late Qing fiction as the originating period of modern Chinese literature. The "re-discovery" of the Beijing and Shanghai Modernist schools of the I920s and I930s provided a feasible alternative to mainstream realism. Hence writers were no longer grouped according to their political or ideological affiliations but by gender, provenience, geographical area, literary style or topic, yet histories of literatures from Taiwan and Hong Kong were practically non-existent. One of the first western literary histories of Chinese literature was published in I96I by the Chinese American literary scholar C. T. Hsia (I92I-20I3) and intended to "contradict rather than affirm the communist view of modern Chinese fiction". ${ }^{24}$ In as early as 1986 at an international conference in Günzburg (Germany) with the prospective title $A$ Commonwealth of Chinese Literature, more than sixty scholars, mainly from Europe and the United States, assembled to further adjust the perspective on modern Chinese literature by juxtaposing different literatures from Taiwan, Hong Kong and China, by investigating their translation and circulation and by making

${ }^{23}$ For a concise summary of literary historiography see, Zhang Yingjin, "Modern Chinese Literature as an Institution: Canon and Literary History", in The Columbia Companion to Modern East Asian Literature, ed. Joshua S. Mostow (New York: Columbia University Press, 2003), 324-332.

${ }^{24}$ C.T. Hsia, A History of Modern Chinese Fiction (I96I; repr., New York: Columbia University Press, I97I), 498. 
comparisons. ${ }^{25}$ While western China Studies departments were still affected by Cold War sentiments and either bound to Taiwan or the PRC, this seems to be one of the first gatherings with a trans- and inter-local agenda for modern Chinese literature. In the early I990s a paradigmatic shift took place in the field of Chinese literary studies, culminating in a "postcolonial turn" in the field, which at large followed the respective turns and trends in Anglo-American academia. ${ }^{26}$

\section{Identity Politics: Modern Literature and "Chineseness"}

Questions of identity went viral in post-socialist China. The rise of migration, a booming economy, an increasing need for self-assertion of cultural agents and their struggle for normative power provoked different notions of "Chineseness". Although each of those "(self)-definitions" either made place, cultural practice, language or history a marker of difference, every one of them explicitly or implicitly took China as the uncontested centre, as point of departure: "greater China”, “cultural China", "Chinese diaspora”, "overseas Chinese” etc. were basically denoting a detachment from physical space and everyday culture, separated by masses of water, apart from the authentic cultural home. ${ }^{27}$

Neo-Confucian thinker Tu Wei-ming ${ }^{28}$ famously (re)defined "Chineseness" to be located in a Confucian Chinese modernity by

${ }_{25}$ Howard Goldblatt has edited results of this transatlantic cooperation in his book Worlds Apart: Recent Chinese Writing and Its Audiences (Armonk: Sharpe, I990).

${ }_{26}$ To a large extent, contemporary postmodern and postcolonial criticism was the follow up of post-structuralism, New Historicism and New Criticism. For a detailed review of these trends, see Xiaoping Wang, "Three Trends in Recent Studies of Modern Chinese Literature and Culture", China Perspectives 4 (2009), http://chinaperspectives.revues. org/4934.

27 The Tiananmen massacre in 1989 functioned as a sort of watershed for re-questioning "Chineseness", Chinese culture and Chinese script. This was largely due to the fact that many writers and intellectuals left China for good and settled either in Europe or in the United States.

${ }_{28} \mathrm{Tu}$ Wei-ming was the former director of the Harvard Yen-ching Institute; 
placing the "Chinese periphery" (Taiwan, Hong Kong, Singapore, Chinese overseas communities) - i.e. the Chinese mercantile culture with Confucianism as basis - at the centre of what he calls “cultural China” (wenhua zhongguo 文化中國). While the "roots of Chineseness", such is the implication, are clearly to be found in China, its strongest and most fructiferous "branches", however, have spread "over-the-seas”. Although Tu's conceptualisation dismisses Chinese communism and western capitalism, his metaphor emphasises sinocentric oneness and hierarchy that perceives of Chinese diaspora as an extension of national interests and the culture of origin. The Singapore-based Chinese scholar from Indonesia Wang Gungwu suggests the concept of "local Chineseness" (difangde zhongguoxing 地方的中國性), implying a pragmatic engagement with the local on the basis of a Chinese legacy. ${ }^{29}$ Leo Ou-fan Lee, eminent Chinese US scholar of modern Chinese literature prefers "Chineseness on the move" (youzoude zhongguoxing 遊走的中國性), implying a cosmopolitan being at home nowhere and everywhere but always committed to Chinese culture. ${ }^{30}$

Critical theory and postcolonial interventions have formulated alternative conceptualisations of China/Chinese, which generally aim at accommodating transnationalisation and translingualism on the one hand and "de-nationalising" and "de-sinicising" China/ Chinese on the other. In short: de-constructing China as monolithic entity; re-conceptualising Chinese literature as an inclusive term; re-reading modern Chinese literatures as local appropriations of trans-local and global developments; countering both the "evolutionary" narrative, advocated by the New Culture Movement and continued by CCP literary historians, and the tedious dichotomy of "China and the West", which nonetheless still informs a large amount of scholarship.

for reference, see his edited book The Living Tree: The Changing Meaning of Being Chinese Today (Stanford: Stanford University Press, I994).

29 See, for example, his essay publication The Chineseness of China: Selected Essays (Oxford: Oxford University Press, I992).

$3^{\circ}$ For an in-depth insight see his Musings: Reading Hong Kong, China and the World (Hong Kong: East Slope Publishing Limited, 20 I I). 


\section{The Sinophone and Post-loyalist Writing}

Inspired by highly contested and ideologically charged terms like anglophone, francophone, hispanophone and lusophone literatures, which broadly refer to the literatures in the ex-colonies using the ex-colonisers' languages, the term sinophone has become popular in China studies circles. ${ }^{31}$ Most prominently the term has been defined by comparative literature scholar Shu-mei Shih as a critical response to what she calls Middle Kingdom hegemony. Shih coined the notion of sinophone to designate "Sinitic-language cultures and communities outside China as well as those ethnic communities in China where Sinitic languages are either forcefully imposed or willingly adopted".32 Sinophone articulations, in her view, are voices against Han Chinese nationalism, originating from ethnic minority territories like Tibet, Xinjiang, Mongolia, Taiwan or Hong Kong. Shih is critical towards the notion of diaspora, which she considers being a unifying Han-centred Chinese identity category, denoting a hegemonic relationship between a nation and its nationals abroad. The sinophone is hardly a spatial concept only but above all an "analytical and cognitive category therefore both geographically and temporally specific [...] a placebased, everyday practice and experience, and thus a historical formation that constantly undergoes transformation to reflect local needs and conditions. It can be a site of both a longing for and rejection of various constructions of Chineseness". ${ }^{33}$ Shih's definition of sinophone is therefore not only counterhegemonic but also inherently comparative and transnational.

David der-wei Wang refutes Shih's postcolonial concept, stressing the heteroglossia and diversity of Chinese languages with their

3r Sinophone can only partly be an equivalent; as for example the British colonised Hong Kong and Malaysia and Taiwan was colonised by the Japanese and not by "China proper". Besides the Chinese script has been used throughout Asia for centuries before countries like Japan or Korea, developed their own national scripts.

32 Shu-mei Shih, "Against Diaspora: The Sinophone as Places of Cultural Production", in Global Chinese Literature: Critical Essays, edited by Jing Tsu and David Der-wei Wang (Leiden: Brill, 2010), 36.

33 Ibid., 39. 
multitude of Sinitic-Tibetan languages and dialects. Employing Bakhtin's term of "heteroglossia" he emphasises linguistic plurality inside China, despite mono-linguistic control, not only as a literary technique but also as a sign of "Chineseness". Adopting a historical perspective, he builds his argument on the fact that Chinese history is less a history of colonialism than a history of migration, with millions of Chinese being forced or having chosen to leave their homeland and to settle mainly in East and South East Asia (a statement, which does not contradict but rather strengthen Shu-mei Shih's concept of the sinophone). In his essay "Literary Traveling and World Imagination" from 2006, Wang uses the term Sinophone Literature as denoting all literatures in the Chinese language whether produced inside or outside China. ${ }^{34}$ This additive definition is peppered by the concept of Post-loyalist writing (houyimin xiezuo 後遺民寫作), a term closely related to the notion of diaspora referring to migrants who keep alive their memories of an imaginary homeland. Post-loyalism, as Wang explains, does not refer to an ideology but serves as a critical interface through which to analyse political unconsciousness and cultural fixation. 35

The least common denominator that these varied concepts of the Sinophone seem to share is to think beyond "Chineseness" and to de-nationalise and de-sinicise modern Chinese literature. So does the national imagery still play any role in writing and reading literature at all? What safeguards the coherence of modern Chinese literature?

34 Sinophone literature integrates the different concepts of "literature in Chinese" (huayu wenxue 華語文學), “China Literature” (zhongguo wenxue 中國文學), “overseas Chinese literature” (haiwai huawen wenxue 海外華文文學), “world Chinese literature” (shijie huawen wenxue 世界 華文文學) and “Taiwan, Hong Kong, Singapore, Malaysia sojourners” literature in Chinese" (tai xiang xing ma lisan huawen wenxue 台香星 馬離散華文文學)， see David Der-wei Wang, “Wenxue xinglü yu shijie xiangxiang” [Literary traveling and world imagination 文學行旅與世界 想像], Mingpao Monthly, July 2006.

35 For more details see his lecture at Cambridge University in 2014, "Sailing to the Sinophone World: On Modern Chinese Literary Cartography”. https://www.youtube.com/watch?v=2F $5 \mathrm{ZdEyMgA} 8$. 
When the eminent literary scholar C. T. Hsia in I96I published his seminal work, A History of Modern Chinese Fiction, I9I7-I957, he explained the impossibility for Chinese literature to transcend China's borders and become world literature due to Chinese writers' "obsession with China". This clearly no longer holds true, however, "Chinese literature" still can be identified as a heavy burden on the shoulders of "Chinese writers". Yet American sinophone writer Ha Jin clearly votes against writing "national allegories" ${ }^{6} 6$ and strongly objects to nationalistic, patriotic or any form of loyalist writing. $\mathrm{He}$ rejects the role of cultural ambassador mediating between China and the west or vice versa. ${ }^{37}$ French sinophone writer Gao Xingjian in his Nobel Lecture leaves no doubt that he speaks "in the voice of an individual ... not as a spokesperson of the people ..." ${ }^{8} 8$ These voices hardly harbour any desire for national or ethnic affiliation or post-loyalist ancestral belonging. That is why a conceptualisation of sinophone as analytical and cognitive category as well as a placebased, everyday practice actually may show a way out of essentialist notions of "Chineseness" and allow for critical positions debunking Chinese nationalism and Han-ethnocentrism.

\section{Bibliography}

Anderson, Marston. The Limits of Realism: Chinese Fiction in the Revolutionary Period. Berkeley: University of California Press, I990.

Chakrabarty, Dipesh. Provincializing Europe: Postcolonial Thought and Historical Difference. New Jersey: Princeton University Press, 2000.

${ }^{36}$ See Fredric Jameson, "Third-World Literature in the Era of Multinational Capitalism," Social Text I 5 (Autumn I986): 65-88, where he argues that all third-world texts can be read as national allegories, as their forms developed out of western modes of representation.

37 Instead Ha Jin builds his own writing experience on the model given by Conrad and Nabokov, who both found their destinies in their adopted language, see "Exiled to English," in Sinophone Studies: A Critical Reader, edited by Shu-mei Shih, Chien-hsin Tsai and Brian Bernhards (New York: Columbia University Press, 20I3): I I7-I 24.

${ }^{38}$ Gao Xingjian, "The Case for Literature”, The Nobel Prize in Literature 2000, accessed I5 May 20I7, http://www.nobelprize.org/nobel_prizes/ literature/laureates/2000/gao-lecture-e.html. 
Dirlik, Arif. "Literary Identity/Cultural Identity: Being Chinese in the Contemporary World". Modern Chinese Literature and Culture Resource Center Publication, September 20I3. https://u.osu.edu/ mclc/book-reviews/literary-identity/.

Callahan, William A. "National Insecurities: Humiliation, Salvation, and Chinese Nationalism". Alternatives 29 (2004): I99-2 I 8.

des Forges, Alexander. "The Rhetorics of Modernity and the Logics of the Fetish". In Contested Modernities in Chinese Literature, edited by Charles A. Laughlin, I7-3 I. New York: Palgrave Macmillan, 2005 .

Gao, Xingjian. "The Case for Literature". The Nobel Prize in Literature 2000. Accessed I 5 May 20I7. http://www.nobelprize. org/nobel_prizes/literature/laureates/200o/gao-lecture-e.html.

Goldblatt, Howard. Worlds Apart: Recent Chinese Writing and Its Audiences. Armonk: Sharpe, I990.

Ha Jin. “Exiled to English”. In Sinophone Studies: A Critical Reader, edited by Shu-mei Shih, Chien-hsin Tsai and Brian Bernhards, I 7-I24. New York: Columbia University Press, 2013.

Hsia, C. T. A History of Modern Chinese Fiction. I96r. Reprint, New York: Columbia University Press, I97I.

Jameson, Fredric. "Third-World Literature in the Era of Multinational Capitalism”. Social Text I 5 (Autumn I986): 65-88.

Jusdanis, Gregory. Belated Modernity and Aesthetic Culture: Inventing National Literature. Minneapolis: University of Minnesota Press, I99I.

Kaufman, Alison Adcock. "The 'Century of Humiliation,' Then and Now: Chinese Perceptions of the International Order". Pacific Focus 25, no. I (2010): I-33.

Kenley, David. New Culture in a New World: The May Fourth Movement and the Chinese Diaspora in Singapore, I919-1932. New York: Routledge Press, 2003.

Laughlin, Charles A. "Introduction". In Contested Modernities in Chinese Literature, edited by Charles A. Laughlin, I-I4. New York: Palgrave Macmillan, 2005. 
Lee, Leo Ou-fan. Musings: Reading Hong Kong, China and the World. Hong Kong: East Slope Publishing Limited, 20I I.

Mair, Victor H. "What is a Chinese 'Dialect/Topolect'? Reflections on Some Key Sino-English Linguistic Terms”. Sino-Platonic Papers 29 (September I99I): I-3I.

Peterson, Rachelle. "American Universities Are Welcoming China's Trojan Horse”. Foreign Policy. 5 September 2017.

Pollock, Sheldon. "The Cosmopolitan Vernacular". The Journal of Asian Studies 57, no. I (February I998): 6-37.

Ramsey, Robert. The Language of China. Princeton: Princeton University Press, 1987.

Said, Edward. Orientalism. New York: Pantheon Books, I978.

Shih, Shu-mei. The Lure of the Modern: Writing Modernism in Semicolonial China, I917-1937. Berkeley: University of California Press, 200I.

—. "Against Diaspora: The Sinophone as Places of Cultural Production”. In Global Chinese Literature: Critical Essays, edited by Jing Tsu and David Der-wei Wang, 29-48. Leiden: Brill, 20 Iо.

Tu, Wei-ming. The Living Tree: The Changing Meaning of Being Chinese Today. Standford: Stanford University Press, I994.

Wang, David Der-wei. “Wenxue xinglü yu shijie xiangxiang” [Literary traveling and world imagination文学性旅与世界想象]. Mingpao Monthly. July 2006.

- Houyimin xiezuo [Post-loyalist writing 後移民寫作]. Taibei: Maitian Publishing House, 2007.

-. "Sailing to the Sinophone World: On Modern Chinese Literary Cartography". Lecture at Cambridge in 20I4. https:// www.youtube.com/watch?v=2F $5 \mathrm{ZdEyMgA} 8$.

Wang, Gongwu. The Chineseness of China: Selected Essays. Oxford: Oxford University Press, I992.

Wang, Ning. "The Mapping of Chinese Postmodernity". In "Postmodernism in China". Special issue, boundary 2 24, no. 3 (Autumn I997): I9-40. 
Yu, Dafu. “Chenlun” [Sinking 沉沦, I92I] http://millionbook.net/ $\mathrm{mj} / \mathrm{y} / \mathrm{yudafu} / \mathrm{ydfz} / \mathrm{ooz}$.htm.

Zhang, Yingjin, "Modern Chinese Literature as an Institution: Canon and Literary History". In The Columbia Companion to Modern East Asian Literature, edited by Joshua S. Mostow, 324-332. New York: Columbia University Press, 2003.

Zhou, Gang. Placing the Modern Chinese Vernacular in Transnational Literature. New York: Palgrave Macmillan, 20 I I. 